\title{
Equol induced apoptosis via cell cycle arrest in human breast cancer MDA-MB-453 but not MCF-7 cells
}

\author{
EUN JEONG CHOI and TAEHEE KIM
}

Plant Resources Research Institute, Duksung Women's University, 419 Ssangmun-dong, Tobong-ku, Seoul 132-714, Korea

Received October 17, 2007; Accepted January 11, 2008

\begin{abstract}
To investigate the effects of equol on cell cycle distribution and apoptosis in human breast cancer cells, we first determined the antiproliferative effects of various concentrations of equol ( $1 \mathrm{nM}$ to $100 \mu \mathrm{M})$ on MCF-7 and MDA-MB-453 cells at 24, 48 or $72 \mathrm{~h}$ of exposure. Equol significantly inhibited proliferation in MDA-MB-453 cells in a dose- and time-dependent manner. In contrast, equol at low concentrations $(<1 \mu \mathrm{M})$ stimulated proliferation in MCF-7 cells, with increased expression of proliferating cell nuclear antigen (PCNA), and only inhibited proliferation at a high concentration $(100 \mu \mathrm{M})$. Similarly, equol treatment of MDAMB-453 cells resulted in significant cell cycle arrest at the $\mathrm{G}_{1} / \mathrm{S}$ transition and in the $\mathrm{G}_{2} / \mathrm{M}$ phase, whereas it caused the slight cell cycle arrest of MCF-7 cells in the $\mathrm{G}_{2} / \mathrm{M}$ phase after $72 \mathrm{~h}$ of treatment. Also, when cells were treated with 50 and $100 \mu \mathrm{M}$ equol for $72 \mathrm{~h}$, the equol affected cell cycle regulatory proteins more significantly in MDA-MB-453 than in MCF-7 cells. During equol-induced apoptosis, equol increased the number of cells in the sub- $\mathrm{G}_{0}$ phase and enhanced the level of p53. The expression of Bax and cytochrome c, downstream targets of p53, was markedly increased by treatment with higher concentrations of equol. Equol-induced cell cycle arrest and apoptosis apparently involves a p53-dependent pathway in different types of breast cancer cells.
\end{abstract}

\section{Introduction}

Several researchers have demonstrated associations between cell proliferation and the cell cycle in cancer $(1,2)$, such that inhibitory effects on the proliferation of cancer cells can occur through the differential regulation of the cell cycle, leading to apoptosis or necrosis. A number of reports have also suggested that cell cycle control points, such as the $G_{1} / S$ and $G_{2} / M$ transitions, are potential targets for chemoprevention and cancer treatment in humans (3-5).

Correspondence to: Dr Eun Jeong Choi, Plant Resources Research Institute, Duksung Women's University, 419 Ssangmun-dong, Tobong-ku, Seoul 132-714, Korea

E-mail: ejchoi@duksung.ac.kr

Key words: breast cancer, cell cycle, cell proliferation, equol
Recently, flavonoids have been proposed as potential chemotherapeutic agents owing to their biological activities, which include effects on cell cycle arrest and apoptosis induction (6-8).

Epidemiological studies have indicated that Asian populations consuming higher amounts of isoflavones have a lower incidence of cancer and cardiovascular disease than do Western populations, who consume lower amounts of isoflavones (9-13). Equol (7-hydroxy-3-(4'-hydroxyphenyl)-chroman) is a major metabolite of the isoflavone daidzein. Interestingly, some people are able to metabolize daidzein into equol (equol producers), and others are not (non-equol producers). Like other flavonoids, equol has antioxidant activity and the ability to act as a hydrogen/electron donor; it can thus scavenge free radicals (14-16). Equol also possesses estrogenic activity, with affinity for both estrogen receptors, ER $\alpha$ and ERß (17-19).

However, until recently the biological effects of equol have not been as well understood as those of daidzein. Only a few reported studies are available regarding the antiproliferative effects of equol and the mechanisms through which it promotes cell cycle arrest. In the present study, we investigated the antiproliferative effects of equol and explored the cell cycle control mechanism underlying these effects in breast cancer MCF-7 and MDA-MB-453 cells.

\section{Materials and methods}

Cell culture and equol treatment. Human breast cancer MCF-7 and MDA-MB-453 cells were purchased from the KCLB (Korean Cell Line Bank, Korea). Cells were routinely maintained in RPMI-1640 (Gibco), supplemented with $10 \%$ FBS and antibiotics $(50 \mathrm{U} / \mathrm{ml}$ of penicillin and $50 \mu \mathrm{g} / \mathrm{ml}$ streptomycin, Gibco) at $37^{\circ} \mathrm{C}$ in a humidified atmosphere containing $5 \% \mathrm{CO}_{2}$. In cell proliferation and cell cycle analysis experiments, cells were treated with either equol or vehicle alone for 24, 48 and $72 \mathrm{~h}$. Daidzein and equol were purchased from Sigma and LC Laboratories (MA, USA), respectively, and dissolved in DMSO (final concentration $0.1 \%$ in medium).

Cell proliferation. Cell proliferation was determined using the MTT assay. At 24, 48 and $72 \mathrm{~h}$, the cells exposed to equol were added to methylthiazolyl tetrazolium (MTT). Four hours later, DMSO was added to each well to dissolve the resulting formazan crystals, and then absorbance was recorded at $540 \mathrm{~nm}$ in a microplate reader (SpectraMax Plus; Molecular Devices). 

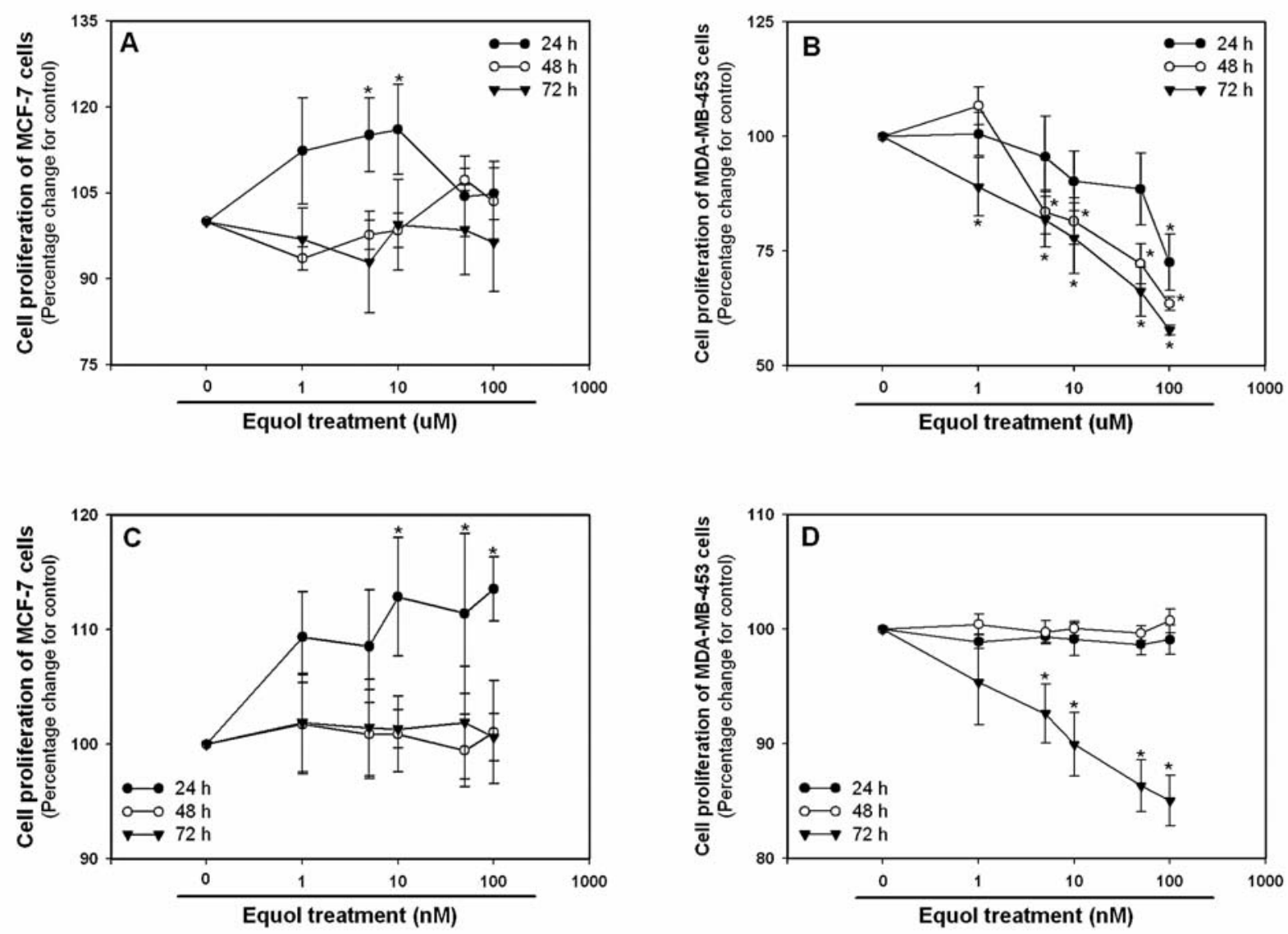

Figure 1. Effect of equol on cell proliferation in human breast cancer MCF-7 (A and C) and MDA-MB-453 (B and D) cells. Cells were exposed to equol at various concentrations (ranging from $1 \mathrm{nM}$ to $100 \mu \mathrm{M}$ ) and incubated for 24, 48 and $72 \mathrm{~h}$. All data were expressed as the percentage change in comparison with the vehicle-only group, which was arbitrarily assigned $100 \%$ viability. ${ }^{*} \mathrm{P}<0.05$, significantly different from the vehicle-only group $(0.1 \%$ DMSO in medium; i.e., an equol concentration of 0 ).

Cell cycle distribution. Cells were harvested, washed with cold PBS and processed for cell cycle analysis. Briefly, the cells were fixed in absolute ethanol and stored at $-20^{\circ} \mathrm{C}$ for later analysis. The fixed cells were centrifuged at $1,000 \mathrm{rpm}$ and washed twice with cold PBS. RNase A ( $20 \mu \mathrm{g} / \mathrm{ml}$ final concentration) and propidium iodide staining solution $(50 \mu \mathrm{g} /$ $\mathrm{ml}$ final concentration) was added to the cells and incubated for $30 \mathrm{~min}$ at $37^{\circ} \mathrm{C}$ in the dark. The cells were analyzed with a FACScalibur instrument (BD Biosciences, San Jose, CA) equipped with CellQuest 3.3 software. ModFit LT 3.1 trial cell cycle analysis software was used to determine the percentage of cells in the different phases of the cell cycle.

Immunoblotting. Protein expression was determined by Western blotting. Briefly, cells were lysed in RIPA buffer (1\% NP-40, $150 \mathrm{mM} \mathrm{NaCl}, 0.05 \%$ DOC, $1 \%$ SDS, $50 \mathrm{mM}$ Tris, $\mathrm{pH}$ 7.5) containing protease inhibitor for $1 \mathrm{~h}$ at $4^{\circ} \mathrm{C}$. The supernatant was separated by centrifugation and protein concentration was determined by the Bradford Protein Assay Kit II (Bio-Rad Laboratories, CA, USA). Proteins (25 $\mu \mathrm{g} /$ well) denatured with sample buffer were separated by $10 \%$ SDS-polyacrylamide gel, then transferred onto nitrocellulose membranes $(0.45 \mu \mathrm{m})$. The membranes were blocked with a $1 \%$ BSA solution for $3 \mathrm{~h}$ and washed twice with PBS containing $0.2 \%$ Tween- 20 , then incubated with the primary antibody overnight at $4^{\circ} \mathrm{C}$. Primary antibodies and the housekeeping gene $\beta$-actin were purchased from Cell Signaling Technology Inc., CA, USA and used to probe the separate membranes. The next day, the immunoreaction was continued with the secondary goat anti-rabbit horseradish peroxidaseconjugated antibody after washing for $2 \mathrm{~h}$ at room temperature. One specific protein band for PCNA was revealed by the Enhanced Chemiluminescence Kit (Amersham). The others were detected by the Opti-4CN Substrate Kit (Bio-Rad).

Statistical analyses. All data were expressed as a percentage compared to vehicle-treated control cells, which were arbitrarily assigned $100 \%$. Data were analyzed by one-way analysis of variance followed by Dunnett's multiple comparison test (SigmaStat, Jandel, San Rafael, CA, USA). For all comparisons, differences were considered statistically significant at $\mathrm{p}<0.05$.

\section{Results}

Inhibition of cell proliferation by equol. The effects of equol on proliferation were assessed in human breast cancer MCF-7 and MDA-MB-453 cells, by MTT assay. At concentrations of 1-100 $\mu \mathrm{M}$, equol significantly inhibited cell proliferation in a dose- and time-dependent manner in MDA-MB-453 cells, 


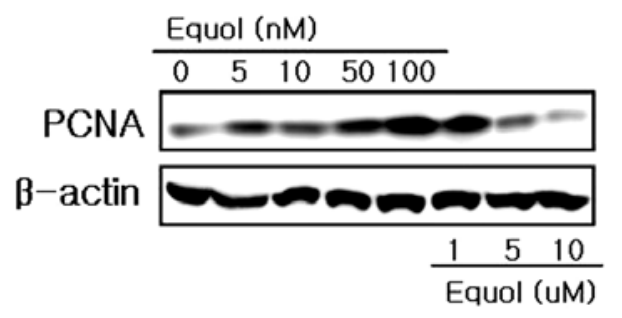

Figure 2. Effect of equol on PCNA expression in human breast cancer MCF-7 cells. Cells were exposed to equol at various concentrations (ranging from $5 \mathrm{nM}$ to $10 \mu \mathrm{M})$ and incubated for $24 \mathrm{~h}$.

but not in MCF-7 cells (Fig. 1A). Significant anti-proliferative effects were observed at $24 \mathrm{~h}$ in MDA-MB-453 cells treated with $100 \mu \mathrm{M}$ equol. After more than $48 \mathrm{~h}$ of exposure, cell proliferation was significantly decreased at low equol concentrations $(\mathrm{p}<0.05)$. Treatment with equol at a high concentration for $72 \mathrm{~h}$ decreased MDA-MB-453 cell proliferation by up to $57.7 \%$ compared to the controls. In contrast, cell proliferation was significantly increased in MCF-7 cells treated with 1 to $<10 \mu \mathrm{M}$ equol for $24 \mathrm{~h}$, although equol did not affect cell proliferation at 48 or $72 \mathrm{~h}$ (Fig. 1B).

To further evaluate the effect of equol on cell proliferation, MCF-7 and MDA-MB-453 cells were treated with very low concentrations (1-100 nM) for 24, 48 and $72 \mathrm{~h}$. In MCF-7 cells, equol at very low concentrations significantly increased cell proliferation at $72 \mathrm{~h}$, although there was no change at 24 or $48 \mathrm{~h}$. Specifically, exposure to 10,50 and $100 \mathrm{nM}$ equol decreased cell proliferation by $12.8,11.4$ and $13.5 \%$, respectively, compared with the vehicle-only group ( $<<0.05$, Fig. 1C). In MDA-MB-453 cells, equol at very low concentrations showed a significant antiproliferative effect only at $72 \mathrm{~h}$ (Fig. 1D).

Promotion of cell proliferation by equol in MCF-7 cells. To confirm the MTT assay results regarding cell proliferation, MCF-7 cells were treated with equol at various concentrations ( $5 \mathrm{nM}$ to $10 \mu \mathrm{M}$ ) for $24 \mathrm{~h}$ (Fig. 2) and the expression of proliferating cell nuclear antigen (PCNA), a biomarker of cell proliferation, was determined. Increased PCNA expression was observed with equol treatments of $50 \mathrm{nM}$ to $1 \mu \mathrm{M}$. Very low PCNA expression occurred at 5 and $10 \mu \mathrm{M}$ equol.

Equol-induced cell cycle arrest. Exposure to 1-100 $\mu \mathrm{M}$ equol for $72 \mathrm{~h}$ induced significant and dose-dependent cell cycle disruption in MDA-MB-453 cells, but not in MCF-7 cells (Fig. 3). Equol treatment resulted in a decreased number of MDA-MB-453 cells in the $G_{1} / S$ and $G_{2} / M$ phases. The $G_{1} / S$ transition was significantly observed at $5 \mu \mathrm{M}$, as the $\mathrm{G}_{1}$ phase

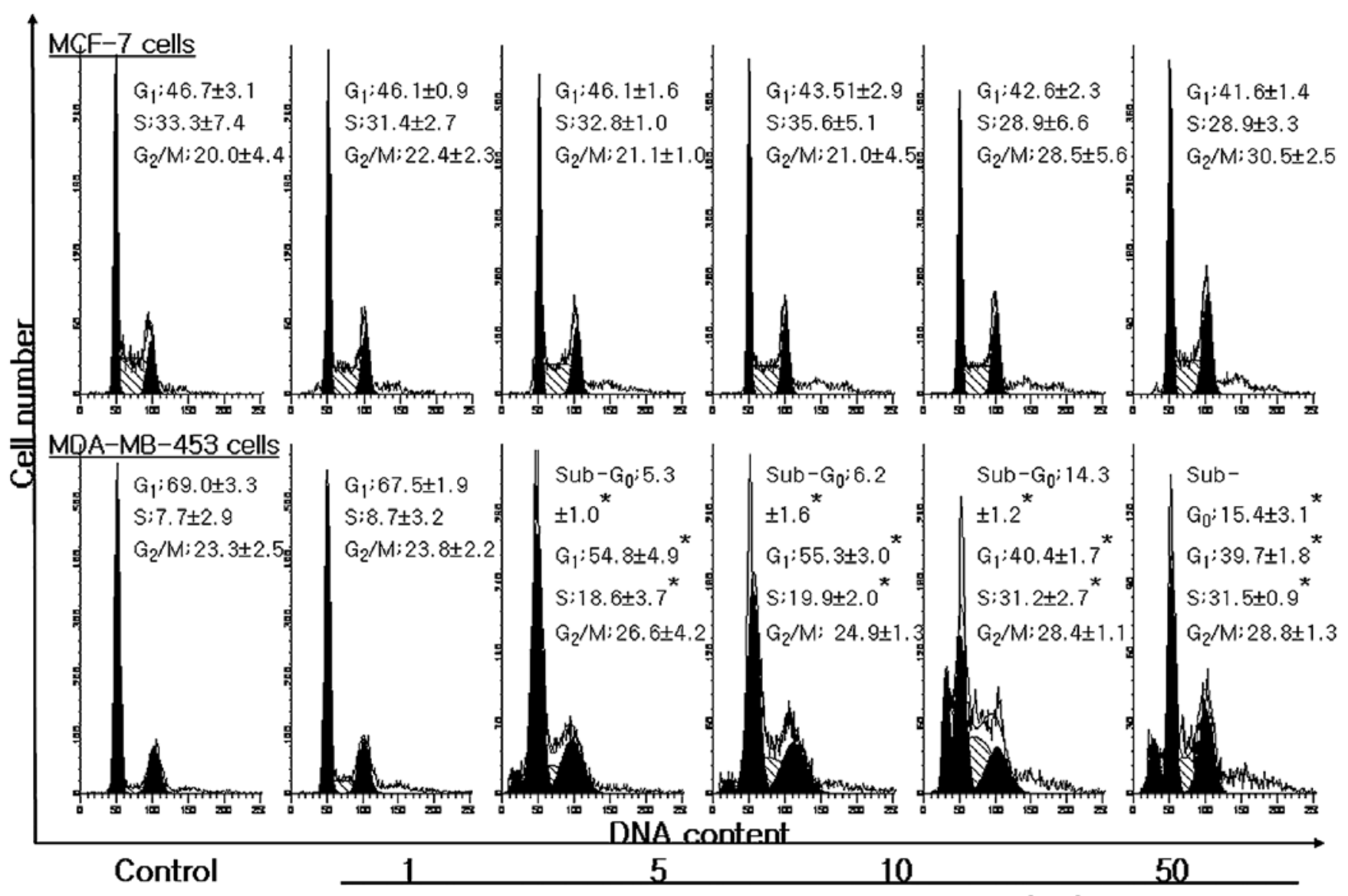

Equol treatment concentration (uM)

Figure 3. Effect of equol on cell cycle arrest in human breast cancer MCF-7 and MDA-MB-453 cells. Cells were exposed to equol at various concentrations (ranging from 1 to $100 \mu \mathrm{M}$ ) and incubated for $72 \mathrm{~h} .{ }^{*} \mathrm{P}<0.05$, significantly different from the vehicle-only group (0.1\% DMSO in medium; i.e., an equol concentration of 0$)$. 


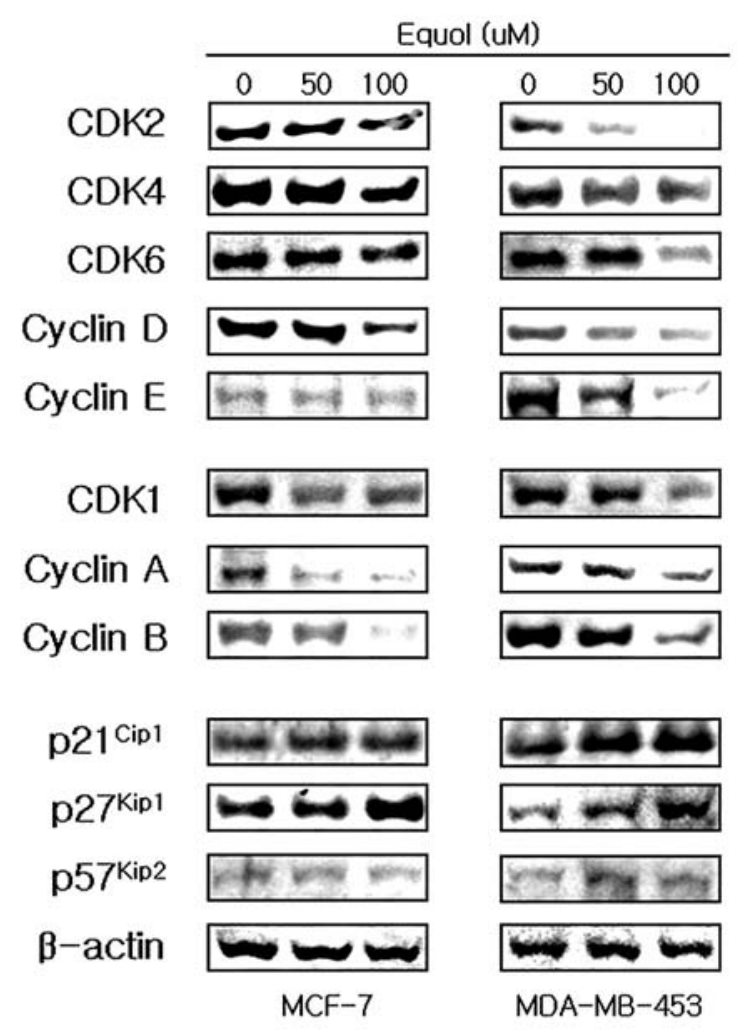

Figure 4. Effect of equol on cell cycle regulator protein expression in human breast cancer MCF-7 and MDA-MB-453 cells. Cells were exposed to equol at high concentrations (50 and $100 \mu \mathrm{M})$ and incubated for $72 \mathrm{~h}$.

was accompanied by an increase in cell population in the $\mathrm{S}$ phase. After exposure to 5, 10, 50 and $100 \mu \mathrm{M}$ equol, the proportion of MDA-MB-453 cells in the $\mathrm{G}_{1}$ phase decreased from $69 \%$ to $54.8,55.3,40.4$ and $39.7 \%$, respectively, and the proportion of S-phase cells increased from $18.6 \%$ to 26.6, $19.2,31.2$ and $31.5 \%$, respectively. At 50 and $100 \mu \mathrm{M}$ equol, respectively, the $\mathrm{G}_{2} / \mathrm{M}$ population was slightly increased by 21.8 and $23.6 \%$ compared with the controls. A significant increase in the number of MDA-MB-453 cells in the sub$\mathrm{G}_{0}$ phase was also observed after exposure to $5 \mu \mathrm{M}$ equol. After treatment with higher equol concentrations (50 and $100 \mu \mathrm{M})$, small DNA fragments in the sub- $\mathrm{G}_{0}$ phase increased from $0.9 \%$ to 14.3 and $15.4 \%$, respectively.

In MCF-7 cells, significant cell cycle arrest in the $\mathrm{G}_{2} / \mathrm{M}$ phase (30.5\% of MCF-7 cells compared to $20.0 \%$ of the control cells, $\mathrm{p}<0.05)$ occurred only after treatment with $100 \mu \mathrm{M}$ equol for $72 \mathrm{~h}$. Compared with the control population, the MCF-7 cell population in the $\mathrm{G}_{2} / \mathrm{M}$ phase decreased by 42.5 and $52.5 \%$ at 50 and $100 \mu \mathrm{M}$ equol, respectively.

Effects of equol on cell cycle-related protein expression. We examined the specific regulatory proteins responsible for equol-induced cell cycle arrest in cells treated with high concentrations of equol $(50$ and $100 \mu \mathrm{M})$ for $72 \mathrm{~h}$ (Fig. 4). In MCF-7 cells, equol treatment resulted in a slight reduction in the expression of cyclin D and CDK4 and no detectable change in cyclin $\mathrm{E}, \mathrm{CDK} 2$, and CDK6 expression, compared to their expression in the control cells. In contrast, marked decreases occurred in the expression levels of CDK1 and cyclins A and

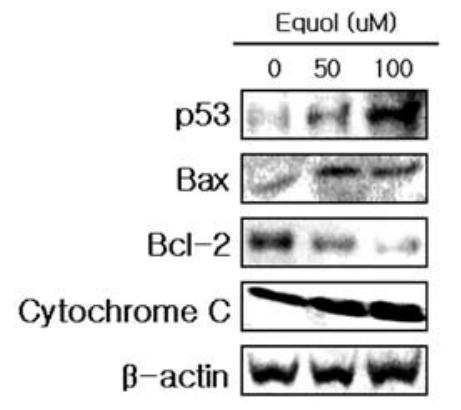

Figure 5. Effect of equol on apoptosis-related gene expression of human breast cancer MDA-MB-453 cells. Cells were exposed to equol at high concentrations (50 and $100 \mu \mathrm{M})$ and incubated for $72 \mathrm{~h}$.

B - which combine with CDK1 to control the $\mathrm{G}_{2} / \mathrm{M}$ phase especially with $100 \mu \mathrm{M}$ equol (Fig. 4B). At maximal treatment with $100 \mu \mathrm{M}$ equol, cyclin $\mathrm{B}$ expression was especially decreased.

In MDA-MB-453 cells, 50 and $100 \mu \mathrm{M}$ equol affected regulatory protein expression, markedly decreasing CDK2 and cyclin E expression in a dose-dependent manner. CDK6 expression was only decreased at $100 \mu \mathrm{M}$, whereas the expression of CDK4 and cyclin D was decreased regardless of equol concentration. Decreased CDK1 expression together with decreased expression of cyclins $\mathrm{A}$ and $\mathrm{B}$ was also observed, as in the MCF-7 cells. In addition, the expression of three inhibitors of cyclin-dependent kinase, p21 Cip1, 227 $7^{\text {Kip } 1}$

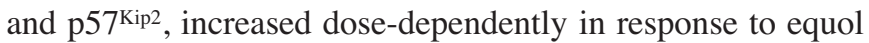
treatment in MDA-MB-453 cells (Fig. 4).

Equol-induced apoptosis. MDA-MB-453 cells were used to investigate equol-induced apoptosis because a strong sub- $\mathrm{G}_{1}$ peak was present in these cells. When MDA-MB-453 cells were treated with high concentrations (50 and $100 \mu \mathrm{M})$ of equol for $72 \mathrm{~h}, \mathrm{p} 53$ expression increased gradually in a dosedependent manner. Additionally, the expression of downstream p53 targets such as Bax and cytochrome c increased markedly at both 50 and $100 \mu \mathrm{M}$ equol (Fig. 5). Under the same conditions, Bcl-2 expression also decreased in a dosedependent manner.

\section{Discussion}

Recently, equol has been considered an important player in the bioactive mechanism of isoflavones such as daidzein, although until now little information has been reported. In the present study, equol affected cell proliferation in different ways, depending on the type of human breast cancer cells used and the absence or presence of estrogen receptors.

Equol significantly inhibited cell proliferation in estrogen receptor-negative MDA-MB-453 cells in a dose- and timedependent manner. This finding is consistent with previous reports indicating that daidzein may be an effective agent against cell growth in some cancer cell types $(20,21)$. Thus, equol apparently has antiproliferative effects similar to its pro-drug, daidzein.

However, at very low concentrations, equol induced proliferation in MCF-7 cells, which have estrogen receptors. This result was supported by increased PCNA expression in 
MCF-7 cells treated with low concentrations of equol. PCNA expression in MCF-7 cells also increased with $50 \mathrm{nM}$ to $1 \mu \mathrm{M}$ equol treatment for $24 \mathrm{~h}$. PCNA is an essential replication factor, synthesized at the initial stages of the $G_{1}$ phase, and has a long half-life, accumulating in the nucleus until mitosis. PCNA is related to the initiation of cell cycle progression and is a useful marker of cell proliferation (22).

Previous studies have suggested that equol, acting as an estrogen-like bioactive molecule, might stimulate tumor cell growth, given that equol has stronger in vitro estrogenic properties than daidzein (23). Additionally, equol has been reported to show proliferative effects on MCF-7 cell growth in vitro $(24,25)$, consistent with our results indicating that the exposure of MCF-7 cells to equol significantly stimulated cell proliferation.

To investigate the apoptosis pathway via cell cycle arrest induced by equol, we first analyzed cell cycle arrest in human breast cancer MCF-7 and MDA-MB-453 cells at various equol concentrations (1-100 $\mu \mathrm{M})$ for $72 \mathrm{~h}$. In MCF-7 cells, cell cycle arrest was not induced at low concentrations of equol, but significant $\mathrm{G}_{2} / \mathrm{M}$ phase arrest was induced at the maximal concentration $(100 \mu \mathrm{M})$. Additionally, in support of $\mathrm{G}_{2} / \mathrm{M}$ phase arrest, there were marked decreases in the amount of CDK1 (Cdc2) protein, cyclin A and cyclin B, but levels of $\mathrm{G}_{1}$ phase-related cell cycle regulator proteins, such as CDK2, CDK4 and cyclin D, were only slightly decreased by equol treatment. CDK1 is a catalytic subunit of the M-phase promoting factor, which is activated at the $G_{2} / M$ transition and controls the onset of mitosis. Several investigators have shown that $\mathrm{CDK} 1$, in combination with cyclins $\mathrm{A}$ and $\mathrm{B}$, is important in the $G_{2} / M$ phase transition $(26,27)$. In MCF-7 cells treated with equol, down-regulation of CDK1 may be a major cause of $\mathrm{G} / \mathrm{M}$ phase arrest.

In contrast, profound differences were found in the cell cycle arrest of MDA-MB-453 cells in response to equol. These results suggest that equol can induce cell cycle arrest through an ER-independent pathway, rather than an ER-dependent one, because MDA-MB-231 cells are ER $\alpha$-negative, as mentioned above. In the present study, equol caused $\mathrm{G}_{1} / \mathrm{S}$ transition, together with S-phase progression, in MDA-MB-453 cells, and DNA accumulation in the sub $\mathrm{G}_{0} / \mathrm{G}_{1}$ phase was also observed at low concentrations of equol. It has been reported that some flavonoids have the ability to arrest cell growth at more than one stage of the cell cycle (28-31).

Equol affected cell cycle regulatory proteins more significantly in MDA-MB-453 cells than in MCF-7 cells. Cell cycle progression is regulated by the activity of cyclin-dependent kinases (CDKs). At the $\mathrm{G}_{1} / \mathrm{S}$ transition of the cell cycle, cyclins $\mathrm{D}, \mathrm{E}$ and $\mathrm{A}$ associate with CDKs to promote cell cycle progression. The activation of $\mathrm{CDK} 2 /$ cyclin $\mathrm{E}$, which is necessary for DNA replication, is particularly important at the $G_{1} / S$ transition. CDKs are also regulated in part by the cyclin-dependent kinase inhibitors (CKIs), which bind to cyclin/CDK complexes to inhibit CDK activity. There are two CKI families: one contains p21 ${ }^{\text {Cip1 }}$, p2 $7^{\text {Kip1 }}$ and p57 Kip2; and the other the INK4 family, including $\mathrm{p} 16^{\mathrm{INK} 4 \mathrm{a}}, \mathrm{p} 15^{\mathrm{INK} 4 \mathrm{~b}}$, $\mathrm{p} 18^{\mathrm{INK} 4 \mathrm{c}}$ and $\mathrm{p} 19^{\mathrm{INK} 4 \mathrm{~d}}(32)$. CDK2 is the major kinase that allows progression through the $G_{1} / S$ phase and subsequent replication events.
Equol induced a decrease in the expression of CDK2, CDK4, cyclin E and cyclin D, together with a slight decrease in the expression of $\mathrm{G}_{2} / \mathrm{M}$-related regulators such as $\mathrm{CDK} 1$, cyclin A and cyclin B. At the maximal equol concentration, the level of CDK2 was almost zero. CDK2 appears to play a key role in equol-induced $\mathrm{G}_{1} / \mathrm{S}$ phase cell cycle arrest.

Additionally, equol induced a dose-dependent increase in $\mathrm{p} 21^{\mathrm{Cip} 1}$ and $\mathrm{p} 27^{\mathrm{Kip} 1}$ expression in MDA-MB-453 cells. The induction of p27 has been shown to be closely related to the $\mathrm{G} / 1$ transition in cell cycle arrest. It has been reported that $\mathrm{p} 27^{\mathrm{Kip} 1}$, of the Cip/Kin family of CKIs, is regulated by $\mathrm{CDK} 2 /$ cyclin $\mathrm{E}$ to prevent premature entry into the $\mathrm{S}$ phase $(33,34)$.

To further examine equol-induced apoptosis, apoptosisrelated proteins were investigated in MDA-MD-453 cells, which demonstrated significant cell cycle arrest and DNA fragmentation in the sub- $\mathrm{G}_{0}$. In the present study, equol dosedependently increased p53 expression in MDA-MB-453 cells. The tumor suppressor gene p53 is regarded as a key factor in the balance between cell survival and death, via regulation of both the $G_{1}$ and $G_{2} / M$ portions of the cell cycle (35). The activation of p53 in response to DNA damage leads to cell cycle arrest and the inhibition of cell proliferation $(36,37)$. Members of the Bcl-2 family of proteins, located downstream of 553 , are critical regulators of the apoptotic pathway $(38,39)$. These proteins consist of the major antiapoptotic family members $\mathrm{Bcl}-\mathrm{x}(\mathrm{L})$ and $\mathrm{Bcl}-2$, and the major pro-apoptotic proteins Bax and Bak. After exposure to equol (50 and $100 \mu \mathrm{M})$, Bax expression increased along with a decrease in Bcl-2 expression. Bax controls mitochondrial permeability and cytochrome $\mathrm{c}$ expression, and the release of cytochrome $\mathrm{c}$ from mitochondria to the cytoplasm is a key step in the initiation of apoptosis. Our results showed that the activity of cytochrome c was significantly increased in MDA-MB-453 cells following treatment with equol.

In conclusion, our results indicate that equol significantly inhibited cell proliferation and induced cell cycle arrest and apoptosis in ER-negative MDA-MB-453 cells. Considering that equol stimulated or inhibited proliferation in MCF-7 cells depending on the concentration, equol had stronger effects in estrogen-independent pathways. Additionally, this study suggests, for the first time, the mechanisms by which equol induces cell cycle arrest and apoptosis. We propose the existence of multiple pathways, via which equol treatment leads to cell cycle arrest at the $\mathrm{G}_{1} / \mathrm{S}$ transition as a result of upregulated $\mathrm{p} 27^{\mathrm{Kip} 1}$ and down-regulated CDK2, in MDA-MB-453 cells. Equol also produces $\mathrm{G}_{2} / \mathrm{M}$ arrest via down-regulated CDK1 in both MCF-7 and MDA-MB-453 cells. Thus, equol operates by different pathways in different subtypes of breast cancer. Moreover, the p53 pathway and up-regulation of cytochrome c expression may be involved in the anti-cancer pathway of equol-induced apoptotic cell death in MDA-MB453 cells.

\section{Acknowledgements}

This work was supported by a Korean Research Foundation Grant funded by the Korean Government (MOEHRD, KRF2006-311-F00127). 


\section{References}

1. Evan GI and Vousden KH: Proliferation, cell cycle and apoptosis in cancer. Nature 411: 342-348, 2001.

2. Liu MC, Marshall JL and Pestell RG: Novel strategies in cancer therapeutics: targeting enzymes involved in cell cycle regulation and cellular proliferation. Curr Cancer Drug Targets 4: 403-424, 2004.

3. Kohn KW, Jackman J and O'Connor PM: Cell cycle control and cancer chemotherapy. J Cell Biochem 54: 440-452, 1994.

4. Afroze $\mathrm{T}$ and Husain M: Cell cycle dependent regulation of intracellular calcium concentration in vascular smooth muscle cells: a potential target for drug therapy. Curr Drug Targets Cardiovasc Haematol Disord 1: 23-40, 2001.

5. Gardner SN: Cell cycle phase-specific chemotherapy: computational methods for guiding treatment. Cell Cycle 1: 369-374, 2002.

6. Le Marchand L: Cancer preventive effects of flavonoids - a review. Biomed Pharmacother 56: 296-301, 2002.

7. Ren W, Qiao Z, Wang H, Zhu L and Zhang L: Flavonoids: promising anticancer agents. Med Res Rev 23: 519-534, 2003.

8. Kandaswami C, Lee LT, Lee PP, Hwang JJ, Ke FC, Huang YT and Lee MT: The antitumor activities of flavonoids. In Vivo 19: 895-909, 2005.

9. Wu AH, Ziegler RG, Horn-Ross PL, Nomura AM, West DW, Kolonel LN, Rosenthal JF, Hoover RN and Pike MC: Tofu and risk of breast cancer in Asian-Americans. Cancer Epidemiol Biomarkers Prev 5: 901-906, 1996.

10. Wu AH, Ziegler RG, Nomura AM, West DW, Kolonel LN, Horn-Ross PL, Hoover RN and Pike MC: Soy intake and risk of breast cancer in Asians and Asian Americans. Am J Clin Nutr 68: 1437S-1443S, 1998

11. Yang D, Bernstein L and Wu AH: Physical activity and breast cancer risk among Asian-American women in Los Angeles: a case-control study. Cancer 97: 2565-2575, 2003.

12. Neuhouser ML: Dietary flavonoids and cancer risk: evidence from human population studies. Nutr Cancer 50: 1-7, 2004.

13. Bosetti C, Spertini L, Parpinel M, Gnagnarella P, Lagiou P, Negri E, Franceschi S, Montella M, Peterson J, Dwyer J, Giacosa A and La Vecchia C: Flavonoids and breast cancer risk in Italy. Cancer Epidemiol Biomarkers Prev 14: 805-808, 2005.

14. Mitchell JH, Gardner PT, McPhail DB, Morrice PC, Collins AR and Duthie GG: Antioxidant efficacy of phytoestrogens in chemical and biological model systems. Arch Biochem Biophys 360: 142-148, 1998.

15. Rüfer CE and Kulling SE: Antioxidant activity of isoflavones and their major metabolites using different in vitro assays. J Agric Food Chem 54: 2926-2931, 2006.

16. Yuan JP, Wang JH and Liu XL: Metabolism of dietary soy isoflavones to equol by human intestinal microflora - implications for health. Mol Nutr Food Res 51: 765-781, 2007.

17. Garreau B, Vallette G, Adlercreutz H, Wähälä K, Mäkelä T, Benassayag $\mathrm{C}$ and Nunez EA: Phytoestrogens: new ligands for rat and human alpha-fetoprotein. Biochim Biophys Acta 1094: 339-345, 1991.

18. Setchell KD, Brown NM and Lydeking-Olsen E: The clinical importance of the metabolite equol - a clue to the effectiveness of soy and its isoflavones. J Nutr 132: 3577-3584, 2002.

19. Cos P, De Bruyne T, Apers S, Vanden Berghe D, Pieters L and Vlietinck AJ: Phytoestrogens: recent developments. Planta Med 69: 589-599, 2003

20. Dubey RK, Gillespie DG, Imthurn B, Rosselli M, Jackson EK and Keller PJ: Phytoestrogens inhibit growth and MAP kinase activity in human aortic smooth muscle cells. Hypertension 33: 177-182, 1999.
21. Hedlund TE, van Bokhoven A, Johannes WU, Nordeen SK and Ogden LG: Prostatic fluid concentrations of isoflavonoids in soy consumers are sufficient to inhibit growth of benign and malignant prostatic epithelial cells in vitro. Prostate 66: 557-566, 2006.

22. Ogle TF, George P and Dai D: Progesterone and estrogen regulation of rat decidual cell expression of proliferating cell nuclear antigen. Biol Reprod 59: 444-450, 1998.

23. Ju YH, Fultz J, Allred KF, Doerge DR and Helferich WG: Effects of dietary daidzein and its metabolite, equol, at physiological concentrations on the growth of estrogen-dependent human breast cancer (MCF-7) tumors implanted in ovariectomized athymic mice. Carcinogenesis 27: 856-863, 2006.

24. Sathyamoorthy N and Wang TT: Differential effects of dietary phyto-oestrogens daidzein and equol on human breast cancer MCF-7 cells. Eur J Cancer 33: 2384-2389, 1997.

25. Matsumura A, Ghosh A, Pope GS and Darbre PD: Comparative study of oestrogenic properties of eight phytoestrogens in MCF7 human breast cancer cells. J Steroid Biochem Mol Biol 94: 431-443, 2005.

26. Morla AO, Draetta G, Beach D and Wang JY: Reversible tyrosine phosphorylation of cdc2: dephosphorylation accompanies activation during entry into mitosis. Cell 58: 193-203, 1989.

27. Jessus C and Beach D: Oscillation of MPF is accompanied by periodic association between cdc25 and cdc2-cyclin B. Cell 68 323-332, 1992.

28. Reiners JJ, Clift R and Mathieu P: Suppression of cell cycle progression by flavonoids: dependence on the aryl hydrocarbon receptor. Carcinogenesis 20: 1561-1566, 1999.

29. Choi SU, Ryu SY, Yoon SK, Jung NP, Park SH, Kim KH, Choi EJ and Lee CO: Effects of flavonoids on the growth and cell cycle of cancer cells. 1: Anticancer Res 19: 5229-5233, 1999.

30. Singh RP and Agarwal R: Natural flavonoids targeting deregulated cell cycle progression in cancer cells. Curr Drug Targets 7: 345-354, 2006

31. Walle T, Ta N, Kawamori T, Wen X, Tsuji PA and Walle UK Cancer chemopreventive properties of orally bioavailable flavonoids - methylated versus unmethylated flavones. Biochem Pharmacol 73: 1288-1296, 2007.

32. Sherr CJ and Roberts JM: CDK inhibitors: positive and negative regulators of G1-phase progression. Genes Dev 13: 1501-1512, 1999.

33. Nakayama KI, Hatakeyama S and Nakayama K: Regulation of the cell cycle at the G1-S transition by proteolysis of cyclin $\mathrm{E}$ and p27Kip1. Biochem Biophys Res Commun 282: 853-860, 2001.

34. Porter LA, Kong-Beltran M and Donoghue DJ: Spy1 interacts with p27Kip1 to allow G1/S progression. Mol Biol Cell 14: 3664-3674, 2003

35. Agarwal ML, Agarwal A, Taylor WR and Stark GR: p53 controls both the G2/M and the G1 cell cycle checkpoints and mediates reversible growth arrest in human fibroblasts. Proc Natl Acad Sci USA 92: 8493-8497, 1995.

36. Park M, Chae HD, Yun J, Jung M, Kim YS, Kim SH, Han MH and Shin DY: Constitutive activation of cyclin B1-associated cdc2 kinase overrides p53-mediated G2-M arrest. Cancer Res 60: $542-545,2000$

37. Lepik D, Jaks V, Kadaja L, Värv S and Maimets T: Electroporation and carrier DNA cause p53 activation, cell cycle arrest, and apoptosis. Anal Biochem 318: 52-59, 2003

38. Oakes SA, Lin SS and Bassik MC: The control of endoplasmic reticulum-initiated apoptosis by the BCL-2 family of proteins. Curr Mol Med 6: 99-109, 2006.

39. van Delft MF and Huang DC: How the Bcl-2 family of proteins interact to regulate apoptosis. Cell Res 16: 203-213, 2006. 